\title{
The sacred Mahakala in the Hindu and Buddhist texts
}

\author{
Dr. Poonam R L Rana
}

\begin{abstract}
Mahakala is the God of Time, Maya, Creation, Destruction and Power. He is affiliated with Lord Shiva. His abode is the cremation grounds and has four arms and three eyes, sitting on five corpse. He holds trident, drum, sword and hammer. He rubs ashes from the cremation ground. He is surrounded by vultures and jackals. His consort is Kali. Both together personify time and destructive powers. The paper deals with Sacred Mahakala and it mentions legends, tales, myths in Hindus and Buddhist texts. It includes various types, forms and iconographic features of Mahakalas. This research concludes that sacred Mahakala is of great significance to both the Buddhist and the Hindus alike.
\end{abstract}

Key-words: Sacred Mahakala, Hindu texts, Buddhist texts.

\section{Mahakala Newari Pauwa}

\section{Etymology of the name Mahakala}

The word Mahakala is a Sanskrit word . Maha means 'Great' and Kala refers to “Time or Death' . Mahakala means “ Beyond time or Death”(Mukherjee, (1988). NY). The Tibetan Buddhism calls 'Mahakala' NagpoChenpo' meaning the ' Great Black One' and also 'Ganpo' which means 'The Protector'.

\section{The Iconographic features of Mahakala in Hindu text}

\section{In the ShaktisamgamaTantra.}

The male spouse of Mahakali is the outwardly frightening Mahakala (Great Time), whose meditatative image (dhyana), mantra, yantra and meditation. In the Shaktisamgamatantra, the mantra of Mahakala is 'Hum Hum Mahakalaprasidepraside Hrim Hrim Svaha.' The meaning of the mantra is that Kalika, is the Virat, the bija of the mantra is Hum, the shakti is Hrim and the linchpin is Svaha. 
Mahakala has four arms and three eyes, and is of the brilliance of 10,000,000 black fires of dissolution, dwells in the midst of eight cremation grounds, is adorned with eight skulls, seated on five corpses, holding a trident, a damaru, a sword and a kharpa in his hands.

With a beautiful body adorned with ashes from the cremation ground, on various corpses he dallies with Kalika, fondling her and making love with her and fiercely kissing her, surrounded by numbers of loudly shrieking vultures and jackals, adorned with a heap of braided hair, in a deserted place.

Kalika is of the form of the void, ornamented with skulls, with a sweet and charming face, in the midst of that five-fold love-yantra. Her yoni is the wheel of time (kalachakra). (ShaktisamgamaTantra)

\section{Description in Shaktisamgama Tantra}

Shaktisamgama Tantra, the spouse of Kali is extremely frightening. Mahakala has four arms, three eyes and is of the brilliance of 10 million black fires of dissolution, dwells in the midst of eight cremation grounds. He is adorned with eight skulls, seated on five corpses, holds a trident, a drum, a sword and a scythe in his hands.

He is adorned with ashes from the cremation ground and surrounded by numbers of loudly shrieking vultures and jackals. Among his side is his consort Kali and they both represent the flow of time. Both Mahakala and Kali/Mahakali represent the ultimate destructive power of 'Brahman' and they are not bounded by any rules or regulations.

When Mahakala and Mahakali are together they have the power to dissolve even time and space into themselves and exist as void at the dissolution of the universe. They are responsible for the dissolution of the universe at the end of Kalpa. They are also responsible for annihilating great evils and great daemons when other gods, Devas and even Trimurtis fail to do so.

Mahakala and Kali annihilates men, women, children, animals, the world and the entire universe without mercy because they are Kala or Time in the personified form and Time is not bound by anything and Time does not show mercy, nor does it wait for anything or anyone. (www.shivashakti.com Mahakala.htm)

\section{Description in the Mahapasupat Sastra}

"Kāla" refers to "Time" and also "death". Usually kāla is used as a synonym for mrityu (Yama) the god of death. Lord Șiva is the death of even death. We have a legendary example of Bhakta Mārkandēya who was born with a limited lifespan but because he was devoted to Mahādēva when Yama tried to seize his life forces, Mahādēva rescued him from Yama and even killed that Yama who is paradoxically hailed by the name of 'Kāla'. 
Therefore Bhagawān Șiva is the kāla of kāla hence the name "Mahākāla". However, scriptures don't use the term Mahakala always to refer to Shiva in his aspect of Time or Death, but mostly the terms Kāla are used to describe about him alone and only selectively Yama is described.

Mahākāla is beyond the three divisions of Time, and he is the creator of Time and he is the withdrawer of Time as well. Time (kāla) is again of two types, viz. kṣhara and akșhara the former one is withdrawn during cosmic dissolution, the latter which is the 'eternal-time' is nothing but another synonym to call "brahman". Both kinds of Time are Mahadeva alone. This second 'time' which is the supreme and imperishable time is Brahman (Mahākāla'snirguṇa aspect)! (Shvetashvatara Upanishad)

\section{Description in the Veda}

Mahakāla is regarded as Bhagawan-self-originated, nothing generates it. It is without origin. In contrast, kāla is always moving on (ghatisheel), it can never be stopped. The name 'kāla' signifies both time and death. Kāla is responsible for the life and death of each human being. Kāla is the destroyer of all existence, carrying all organisms towards physical destruction. Qualities attached to time are responsible for all happiness and sorrow. These concerns are the domain of Jyotish astrology. (Parashara, 1994)

\section{Description in the Bhagavad Gita}

In the Bhagavad Gita 11.32, Krishna takes on the form of kāla, the destroyer, announcing to Arjuna that all the warriors on both sides will be killed, apart from the Pandavas:

\section{'कालोऽस्मिलोकक्षयकृत्प्रवृद्धोलोकान्समाहर्तुम्इहप्रवृत्तः ।'}

This verse means: "Time (kāla) I am the Mahakala, the great destroyer of the worlds, and I have come here to destroy all people.".( Bhagavad Gita 11.32 )

In the Book Hindu Temple VolII mentions of 'Shiva as Mahakala shares the name and features of 'Kirtimukha (Kala). The Linguyat Legend views that Siva, Sankara, Sarabbha, he seized Narashima who had become very proud after having killed Hiranyakasyapa. Out of Narashimas, severed head Shiva made Kirtimukha.

The legends in Puranas says Kirtimukha should be represented at the entrance of Shiva temple and should be worshipped first on entering the temple.

The image of Shiva in his terrific or ugra form or aspect is termed as Aghora, Bhavava and Mahakala are depicted with bulging eyes, inflated cheeks and tusks etc. (Kramrisch, 1976, N. Delhi) 


\section{Description in the Mahabharata and Haribansa Purana}

Lord Krishna didn't kill Banasura, only defeated him and cut all of his 1000 arms. It's interesting what happened to Banasura. After the battle, Nandi suggested him to dance for Shiva. So in this amputated state he did Tandava for Shiva! After that Lord Shiva made him Mahakala. Mahakala is Banasura. It might have been a test for him, to see if he could still perform in this condition. The description of the dance is wonderful! He danced his eyebrows, produced different sounds, and all this while fully covered in blood.

In the Hindu religious text Mahakala is regarded as the ultimate form of Lord Shiva, the destroyer of all elements. It is believed that there is nothing beyond him, no elements, no dimensions not even time. That is why he is called 'Maha' meaning greater than time or 'Kaal' Kaal is also known as (time or death).

There is another meaning of Mahakala that emphasizes the destructive aspect of time. Everything dies in time: "Time ripens the creatures, Time rots them. "Time" (kala) is thus another name for Yama, the god of death. The name is associated with Shiva in his destructive aspect as Mahakala and is extended to his consort, the goddess Kali, or Mahakali (Mahabharata 1.1.188).

In Kalatantra Mahakala is the patriarchal "God of Time". However, originally "he" was the Universal Great Mother, ruling "birth and death" (which is the foundation of time). His female aspect have restored her original power; linguistically we have to call her "Mahakali", which is the feminine version. Both deal with time and death.

Mahakala is referred to as bringer of death. In many parts of India and Nepal followers of Sanatana Dharama they worship Mahakala to ward away untimely death. In the region of Jharkhand, Odisha, and Northern Bengal they regard wild elephants as Mahakala and worship them.

In the Hindu text, Mahakala is the name of Parama-Shiva or the ultimate form of Godhead, as for example, at the temple in Ujjain, which is mentioned more than once by Kālidāsa. The primary temple or place of worship for Mahakala is Ujjain. Mahakala is also a name of one of Shiva's principal attendants (Sanskrit: Gana), along with Nandi, Shiva's mount and is often represented outside the main doorway of early Hindu temples. (www. mhakala.com ). 


\section{The Hindu Legends on Mahakala}

\section{In the Brahma Purana on 'Shiva Mahakala' there is this myth :}

"Once all the creatures were created and their hunger satiated they began to reproduce. Soon there were too many of them. Brahma could see that the cosmos was choked with too much life. He wondered where he had made an error.

Saraswati pointed out to him that he had forgotten to create death. For life to go on, he realized death was essential. He created Mrityu, He ordered her to go and kill all creatures. Mrityu was horrified of the formidable task and fled.

Shiva found Mrityu crying in a desolate place. He consoled her and assured her that all those who would die would be reborn. So she would be mother even though she would kill.

Thus it came to be that Death became not the end of life but a gateway to a new life. Mrityu took the form of Mahakali, devoured all life and Shiva became Mahakala, the lord of time, the regenerator. Life became a wheel, rotated by Shiva an eternal cycle of births and rebirths.
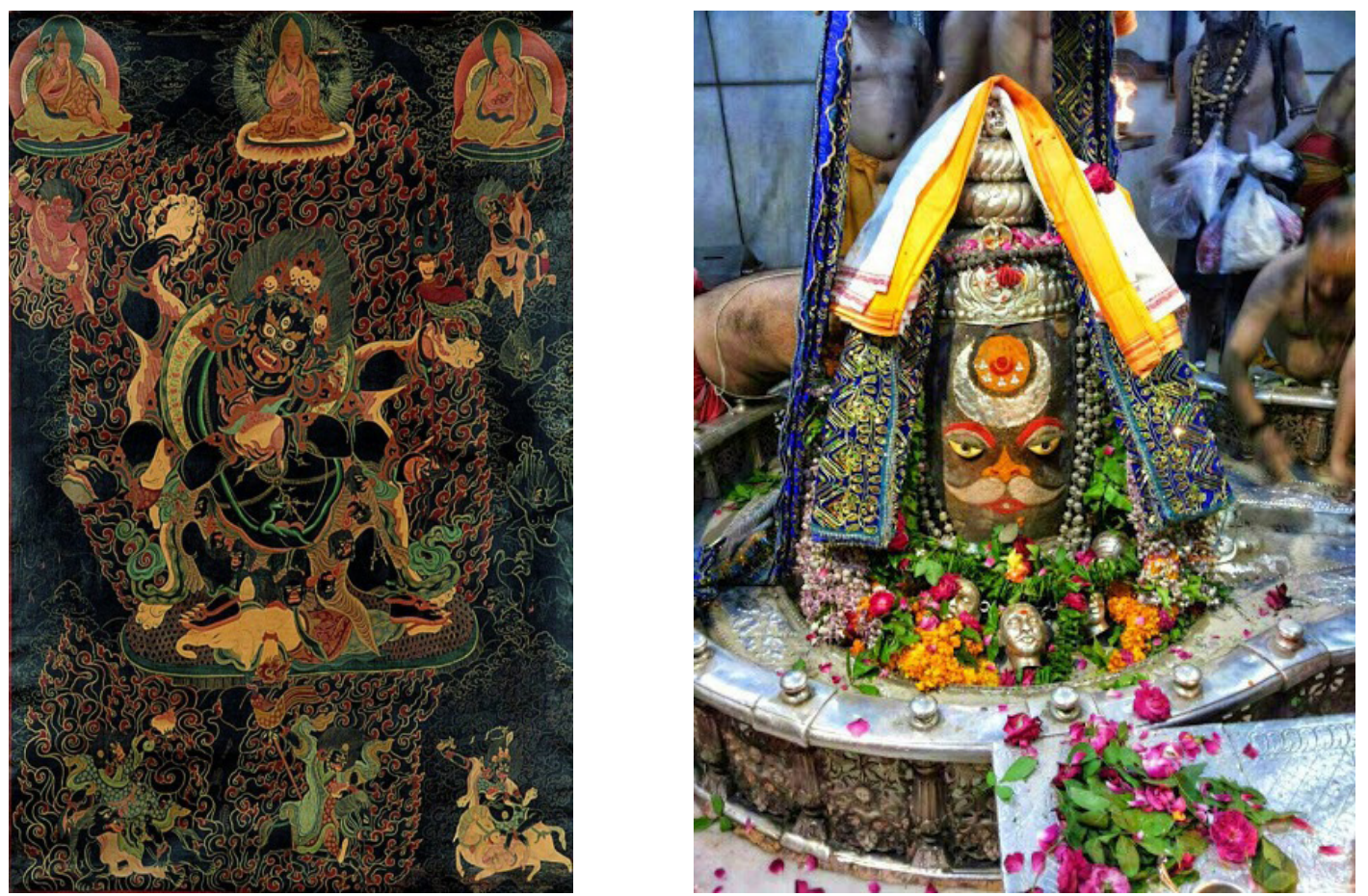

In the Puranas there is a tale related to the oldest Mahakala temple of Ujjain 
In the city of Ujjain was called Avantika and was famous for its beauty and its status as a devotional epicenter. It was also one of the primary cities where students went to study holy scriptures. According to legend, there was a ruler of Ujjain called Chandrasena, who was a pious devotee of Lord Shiva and worshiped him all the time. One day, a farmer's boy named Shrikhar was walking on the grounds of the palace and heard the King chant the Lord's name and rushed to the temple to start praying with him. However, the guards removed him by force and sent him to the outskirts of the city near the river Kshipra. Rivals of Ujjain, primarily King Ripudamana and King Singhaditya of the neighboring kingdoms decided to attack the Kingdom and take over its treasures around this time. Hearing this, Shrikhar started to pray and the news spread to a priest named Vridhi. He was shocked to hear this and upon the urgent pleas of his sons, started to pray to Lord Shiva at the river Kshipra. The Kings chose to attack and were successful; with the help of the powerful demon Dushan, who was blessed by Lord Brahma to be invisible, they plundered the city and attacked all the devotees of Lord Shiva.

Upon hearing the pleas of His helpless devotees, Lord Shiva appeared in his Mahakala form and destroyed the enemies of King Chandrasena. Upon the request of his devotees Shrikhar and Vridhi, Lord Shiva agreed to reside in the city and become the chief deity of the Kingdom and take care of it against its enemies and to protect all his devotees. From that day on, Lord Shiva resided in his light form as Mahakala in a Lingam that was formed on its own from the powers of the Lord and his consort, Parvati. The Lord also blessed his devotees and declared that people who worshipped him in this form would be free from the fear of death and diseases. Also, they would be granted worldly treasures and be under the protection of the Lord himself.

\section{Another Tale}

Bharthari was the elder son of King Gandharva-Sena, and received the kingdom of Ujjain from the celestial god Indra and the King of Dhara.

When Bharthari was king of 'Ujjayani' (modern day Ujjain) in his state there lived a Brahman who after years of austerities was given the fruit of immortality from the celestial tree of Kalpavriksha. The Brahman presented the same to his monarch, Raja Bharthari, who in turn, passed it on to his love, the beautiful, Pinglah Rani or AnangaSena Raja Bhartrhari's youngest wife.

The queen, being in love with the Head police officer of the state, Mahipaala, presented the fruit to him, who further passed it on to his beloved, Lakha, one of the maids of honour. Eventually, Lakha being in love with the king presented the fruit back to the king. Having completed the circle, the fruit revealed the downsides of infidelity to the king, 
he summoned the queen and ordered her beheading, and ate the fruit himself. After that he abdicated the throne, and became a religious mendicant.

He later became a disciple of Pattinatthar (Swetharanyar or Pattinatthu Chettiyar is poorvashram name of this saint from Poompuhar, Tamil Nadu) who first indulged in an argument about samsari and sanyasi with king Bhartrhari. Later during the conversation Pattinathar said that all women have 'dual mind' and it might be the true case even with Parameswari. King conveyed this news to Rani Pingalah and she ordered Pattinathar to get punished and to sit in 'kalumaram' (Tree, whose top portion would be sharpened like a pencil and whole tree is fully coated with oil, a person who is punished to sit in the top will be split into 2 pieces), they tried to kill Pattinathar, but kalumaram started burning and nothing happened to Pattinathar, the king came to know this news and went directly to Pattinathar and asked him to get ready to die the next day, but Pattinathar replied, " I'm ready right now, to die".

The next day king came with tears in his eyes and released saint from jail because he actually noticed queen Pingalah in love with horsemen that night, He threw away his empire, wealth, even full coat dress and dressed in a simple kovanam (loin cloth), the king became a disciple of Pattinatthar and got mukthi (salvation) in Kalahasthi temple. (Jagannathan, 2005, Abhinav Publications)

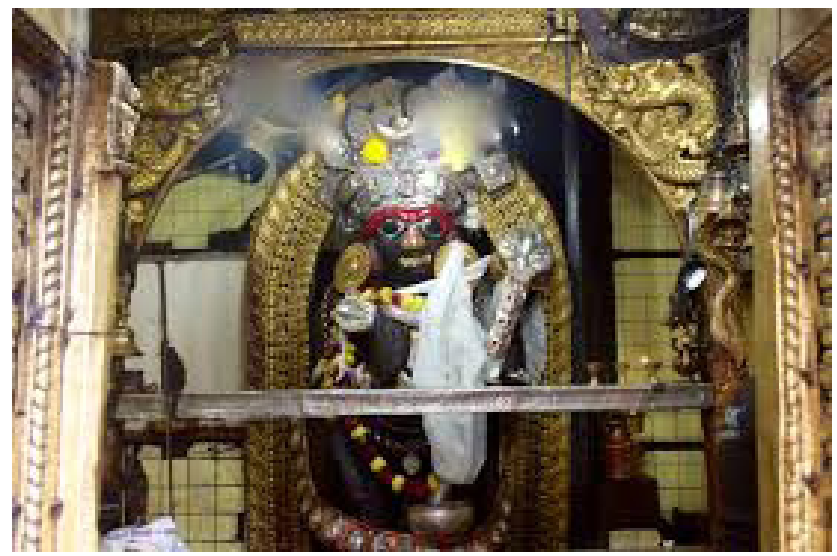

The famous Mahakala temple in Kathmandu

The three-storied temple of Mahakallies West of Tundikhel in Kathmandu, and houses a terrifying idol of the deity.

The idol is made of fine black stone and depicts the deity wearing a garland of human skulls and standing on a dead body with his mouth open, while the nose and ears 
are covered with metal leaflets. The temple is said to have been established by the King Gunakamadeva. The date, is under contradiction.

\section{The Legend}

The legend goes that the temple was founded by a Tantric Guvaju. One day while he was rearing his goat at Tudhikhel hewitnessed the Mahakal flying across the sky towards China . He is believed to have called upon the King Gunakamadeva of Kantipur, where upon the two of them decided to build an idol so as to persuade Mahankal to stay here permanently.

However, Mahakal refused the request but agreed to visit the temple every Saturday. Thus, thousands of people visit the temple on Saturdays as it is believed that the deity himself is present there then.

\section{Mahakala in the Buddhist text}

\section{In the Tibetan Text}

"Mahakalanamo" in the Tibetan text it is said that Mahakala means literally "the great black one" Namo means "hail" or "homage". Mahakala symbolizes the wrathful aspect of the compassionate mind, transforming energies such as anger into a powerful compassionate force.

Mahakala is a Dharmapala, a protector of religious law. He is always depicted as an extremelyfierce and terrifying deity. His purpose is to help in overcoming negative obstacles on the path to enlightenment. A compassionate wrathful deity, he appears evil, like a demon, but functions more like a guard dog, or guardian angel. (Sergent) His aggression is necessary, for it allows him to demolish obstacles and negativities one faces on the path to enlightenment. Mahakala is depicted in a variety of different ways, sometimes with six arms, other times with two. He is often brown skinned and associated in tank as with PendenLhamo.

\section{The Himalayan Resource}

The designation of 'Protector Deity' is common within the Buddhist and Bon religions of the Tibet and Himalayan regions. The term is one designation in a rather fluid yet elaborate set of religious hierarchies in the various pantheons.

There are two types of Protector Deity, first worldly and second beyond worldly. The latter is typically called wisdom or enlightened protector, meaning that they are beyond samsara or worldly existence.

The Buddhist protector deity Mahakala - Mahakala is a wrathful form of the primordial Buddha Vajradhara. In various other forms Mahakala can be an emanation of Akshobhya Buddha or any number of other Buddhas. 
The three main Anuttarayoga Tantra deities of Hevajra, Chakrasamvara and Guhyasamaja each have a specific Mahakala associated with the particular tantra such as: Panjara Mahakala - Panjarnata Tantra (Hevajra), Chaturmukha Mahakala - Guhyasamaja Tantra and the Chaturbhuja Mahakala associated with the various Chakrasamvara Tantras.

Worldly protectors are not enlightened and not considered completely trustworthy. There is a bias in Buddhism to treat all or almost all protectors coming from India to be wisdom protectors. The exception here are the Four Guardian Kings and what are considered the traditional Hindu Gods, often referred to in the Tantras as worldly gods, or protectors.

Numerous mountain gods and indigenous Tibetan and Himalayan deities have been incorporated into the Tantric Buddhist pantheon as worldly deities with the function of a protector. Their job is to safe-guard Buddhism in general, regions, specific monasteries or religious traditions or even a specific text as in the Nyingma Tradition.

\section{The Legend}

\section{Origin of Mahakala}

The compassion of the red Buddha Amitabha manifested as Avalokiteshvara who took a vow to forgo his own enlightenment until all the realms of samsara had been emptied. This vow required a renewal of determination, and so with Amitabha's blessing, Avalokiteshvara next assumed a form with eleven heads and a thousand arms. Still he had been unable to benefit even a few beings.

Therefore after reflecting for one whole week, he determined that by assuming a wrathful form he would be able "to subdue the degenerate beings of this Age of Darkness."

He also saw that even beings who practiced Dharma were unable to escape from the Bardo realms (time between rebirths where beings may face great anxiety and terrifying experiences) and he thought that in wrathful form he could also protect them in that way.

Lastly, he thought that the beings in this Dark Age were poor and needy, experiencing only suffering after suffering, and that in wrathful form he could provide them an antidote to that suffering so that by simply making the wish (for protection) their needs could be met.

These three motives made his determination even greater than before and so from the heart of Noble Avalokiteshvara emerged a dark blue HUNG syllable that immediately became the Instantaneous Protector of Wisdom, Mahakala.

\section{The Different forms of Mahakala}

There are different forms of Mahakala in the Buddhist texts there are 75 forms of Mahakala in Tibetan Buddhism. Iconographically there may be fewer forms but textually there can be an infinite number. Some are as follows: 
- ChaturbhujaVajraNataMahakala (Tibetan: gonpochagshi pa, dor je nag pochenpo. English: The Great Black Vajra Lord with Four Hands) embracing the consort. From the Tradition of AryaNagarjuna. In Tibetan it is known as 'Chagshi pa' the chaturbhujaMahakala has four hands. (This painting is from Bhutan )

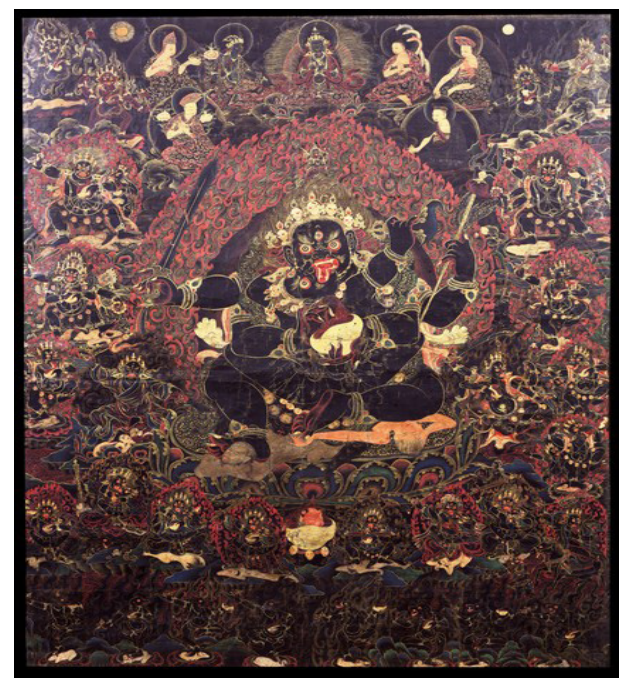

At the top center is the primordial Buddha Vajradhara. At the left are Vajrapani, GaLotsawa and Padma Karpo (PemaKarpo). At the right are Nagarjuna, TsangpaGyare and KunzangJalu.

\section{Iconography}

With one face and four hands, blue-black in colour, Mahakala glares ferociously with three large round eyes, bared fangs and orange hair flowing upward. Has four hands. The first pair of hands hold a fresh heart and the left a skullcup - held to the heart embracing the consort. The second right hand holds upraised a sword and in the left a katvanga staff with a trident point.

Ferocious in appearance the consort holds a skullcup in the left hand. Both are adorned with a tiara of skulls, bone and jewel ornaments, garlands of heads and green silk scarves. The Lord wears a tiger skin as a lower garment and the consort a girdle of finely strung bone ornaments. In a relaxed posture they are seated above a multi-coloured lotus, sun and red corpse seat surrounded by the flames of pristine awareness interspersed with the emanations of black dogs, birds and Garudas.( Jeff Watt 9-2000 ) 


\section{- ShadbhujaMahakala. (Shangpa)}

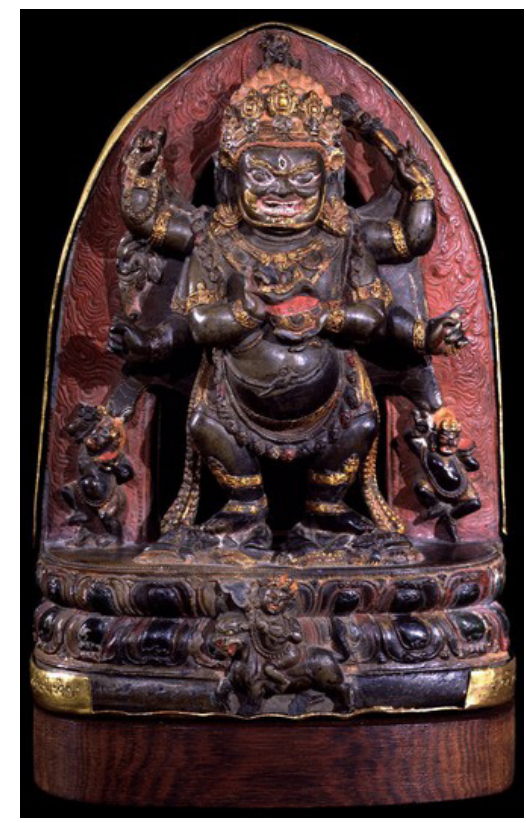

Photo exist at the old Tibetan university

Brought to Tibet by Khyungpo Naljor the founder of the Shangpa Kagyu School (Outline Page), this form of Mahakala became popular in the Sakya, Kagyu and Jonang traditions and was later adopted into the Gelugpa School, becoming the principal protector.

There are other six-armed forms Mahakala that are unrelated to this particular sixarmed Shadbhuja Mahakala.

Shadbhuja Mahakala arises from the Eight-Chapter Mahakala Tantra belonging to the Kriya classification. The interlocutor or sponsor of the tantra was the deity Hayagriva. Mahakala is a general class of protector deities in Tantric Buddhism and primarily associated with the Anuttarayoga Tantras. In general Mahakala forms are wrathful emanations of Vajradhara Buddha. From among the different forms of Mahakala only this Shadbhuja form is an emanation of Avalokiteshvara.

Shadbhuja has a number of different forms recognizable by a variation in body colour, the addition of a consort, hand attributes and retinue figures.

The most popular being the wealth deity White Mahakala practiced in all traditions of Tibetan Buddhism. Variations in appearance are found in the different traditions principally the leg postures of Mahakala, the Gelugpa preferring the more wrathful posture with the legs apart. The Tsarpa lineage of Sakya prefers Shri Devi with four hands so as not to confuse her 
with Magzor Gyalmo the younger sister or servant that has two hands. The colours and hand objects of the remaining retinue also vary according to individual traditions. (Eight-Chapter MahakalaTantra)

\section{Iconography of Shadbhuja Mahakala (Six armed)}

"The Lord of Pristine Awareness has six hands and a body dark blue in colour. The first two hold a curved knife and skullcup, the middle two a human skull mala and trident, the lowest two a damaru drum and lasso.

ShadbhujaMahakala is adorned with a tiger skin, garland of heads, bones and snakes, and small bells on the hands and feet. He has three eyes, bared fangs, eyebrows, beard and hair flowing upward with Akshobhya as a crown. He is anointed with a sindhura drop on the forehead. And behind him is a sandalwood tree, dwelling in the middle of a blazing mass of fire." (JonangTaranatha, 1575-1634).

- Danda Mahakala (Tibetan: gonpobeng leg den nag posri me gyibu): a main wisdom protector of the Nyingma School.

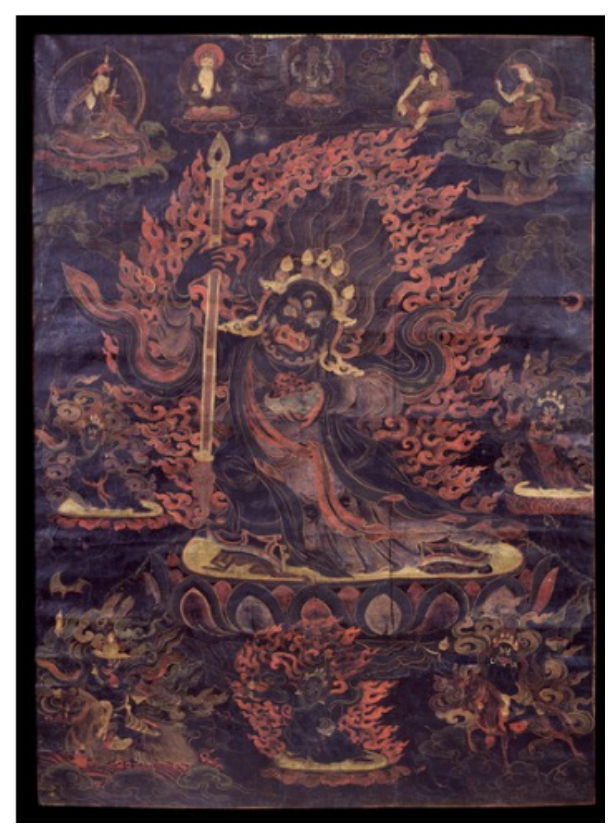

wrathful, black in colour, with one face and two hands he holds upraised in the right a sandalwood staff and a skullcup held to the heart in the left. Wearing a long black cloak he stands atop a corpse seat, sun disc and lotus blossom, surrounded by the flames of wisdom. 
At the top center is the Bodhisattva Avalokiteshvara accompanied by various figures along with Padmasambhava. At the bottom left is the worldly protector Damchen Garwa'iNagpo along with others in the middle and on the right.(Jeff Watt 9-2000 )

- Mahakala, Vajra Panjarnata (Tibetan: dor je gurgyigonpo. English: the Great Black One, Lord of the Vajra Pavilion [or Canopy]): from the Vajra Panjara Tantra.

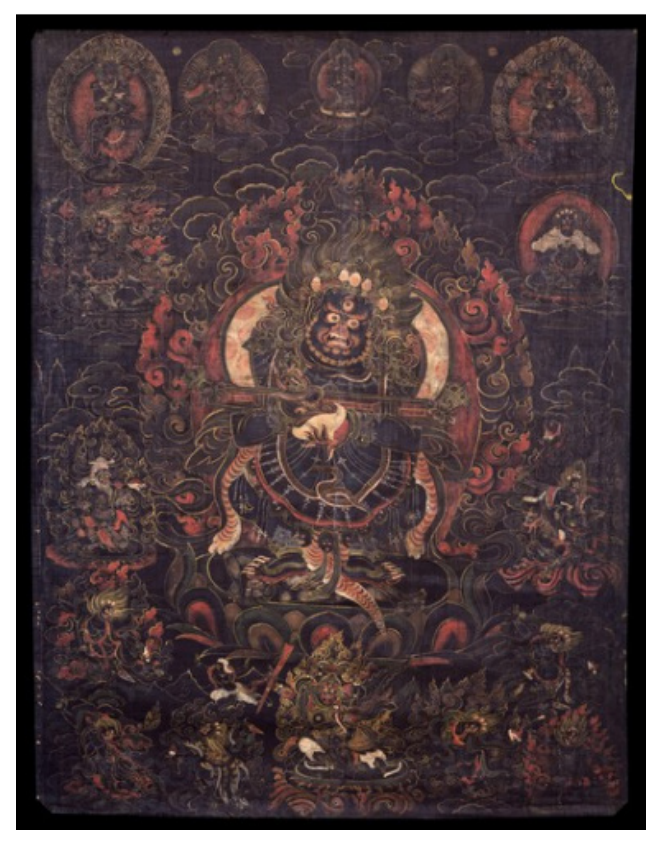

Fiercely wrathful, black in colour with one face, large round eyes, flaming yellow hair and two hands he holds a curved knife in the right and a skullcup in the left - both held to the heart. Resting across the forearms is a 'Gandhi' stick from which all other forms of Mahakala emanate. Adorned with a crown of five dry skulls, bone ornaments and a necklace of fifty freshly severed heads he wears a lower garment of tiger skin. Atop a corpse, circular disc of the sun and multi-coloured lotus he stands surrounded by the flames of pristine awareness.

Seated directly above is the primordial Buddha Vajradhara with one face and two hands holding a vajra and bell crossed at the heart. At each side is a seated Indian Mahasiddha holding a skullcup. At the left corner is Sahaja Hevajra in Heruka form, standing, with one face and two hands holding skullcups crossed at the heart embracing the consort Vajra Nairatmya. At the right is Vajrabhairava in Heruka form with one face and two hands holding a curved knife and skullcup to the heart and riding atop a buffalo. 
PanjaranathaMahakala arises from the Panjara (Pavilion, or canopy) Tantra for which he is the protector and guardian. This Tantra belongs to the Hevajra Cycle of Tantras and classified as Non-dual Anuttarayoga. The method of painting is 'nag thang,' black scroll gold outline on a black background with a lack of superfluous ornamentation and landscape. ( Jeff Watt 6-98 )

- Mahakala Bernagchen (the Black Cloak ) belongs to the class of Bhagavat Mahakala. Bernagchen, Vajra Mahakala (English: the Great Black-Cloak Vajra Mahakala), the personal protector of the Karmapas and the special protector of the Karma Kagyu (Kamtsang) School of Tibetan Buddhism.

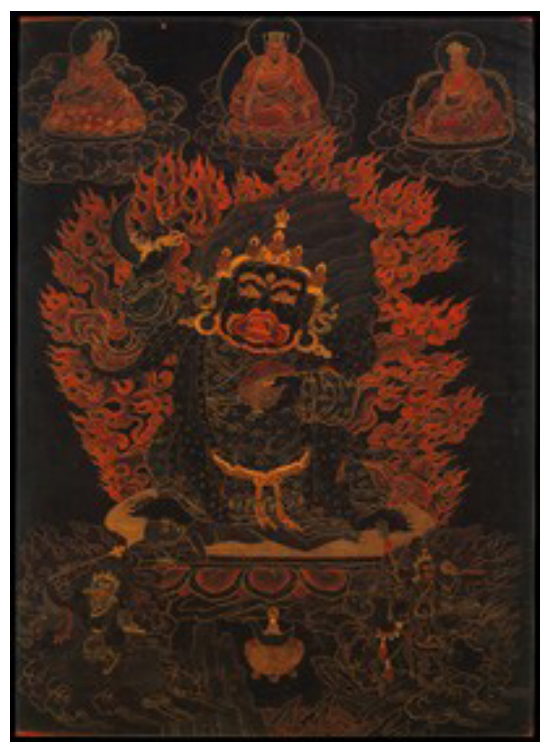

Fresco of the Black Cloak Mahakala (Sameye Monastery)

The Karmapas are a line of successive teachers acknowledged as the first lineage of reincarnating lamas in Tibetan Buddhism. Mahakala is a classification of Buddhist protector deity originating in India. This specific form of Mahakala known as Bernagchen arises from the Nyingma 'Revealed Treasure' Tradition of Tibet and was later introduced into the Karma Kagyu School by the 2nd Karmapa, Karma Pakshi (1206-1283).

The fiercely wrathful, Black Cloak Mahakala is black in colour, with one face, three round bulbous eyes, a large gaping red mouth with bared white fangs. His yellow beard, eyebrows and hair flow upward like flames. The right hand holds aloft a curved flaying knife with a vajra handle. The left holds a white blood filled skullcup to the heart. Adorned with a crown of five dry white skulls, earrings, bracelets and a garland of freshly severed heads, he wears a great black cloak as his unique characteristic. He stands surrounded by black smoke and red licks of the flames of pristine awareness fire. (Jeff Watt 4-2001) 


\section{- Kakamukha (Raven-faced)}

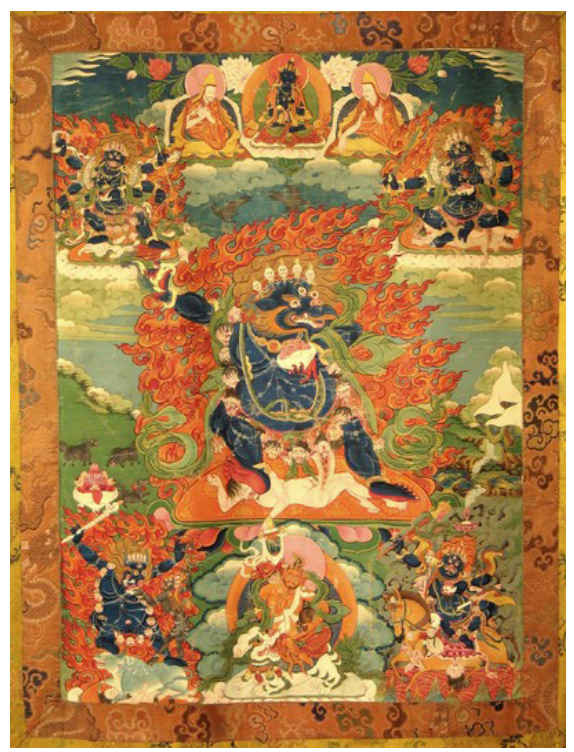

The Raven-faced Mahakala originated from the ChaturbhujaMahakala tradition of GaLotsawa as a retinue figure in the surrounding mandala. Kakamukha is very easy to be confused with the Black Garuda of the Rechungpa system.(Jeff Watt 3-2017)

- MahakalaVyaghraVahana

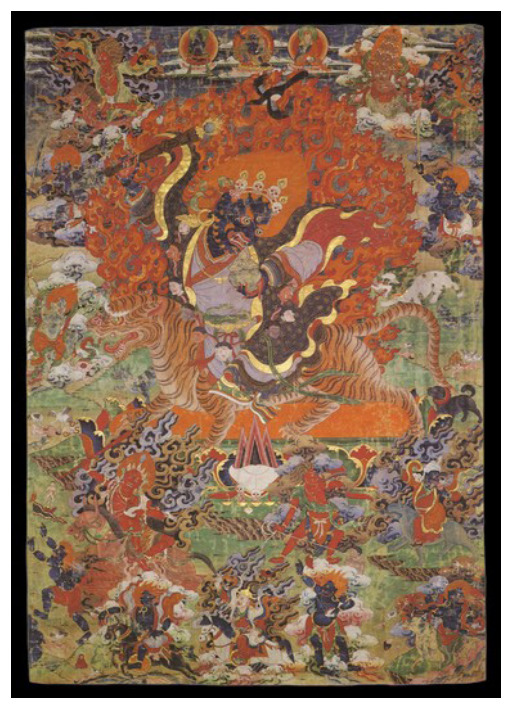

The Tiger Riding Mahakala 'Vyaghra Vahana' appearas to be of Nyingma origin and belongs to the 'Legpa' class of Mahakala deities. So far, known examples in art are related to 
the Thartse Labrang of the Ngor Monastery of Sakya. The Ngor Ewam Monastery has four principal monastic houses: Kangsar, Luding, Thartse and Pende. Each house has a special protector deity. Historically the Kangsar Labrang had the ritual service for Dorje Shugden, the Luding Labrang had the ritual service for Shri Devi Magzor Gyalmo, the Thartse Labrang had the ritual service for Vyaghra Vahana Mahakala.( Jeff Watt 11-2014 )

\section{- Kartaridhara Mahakala}

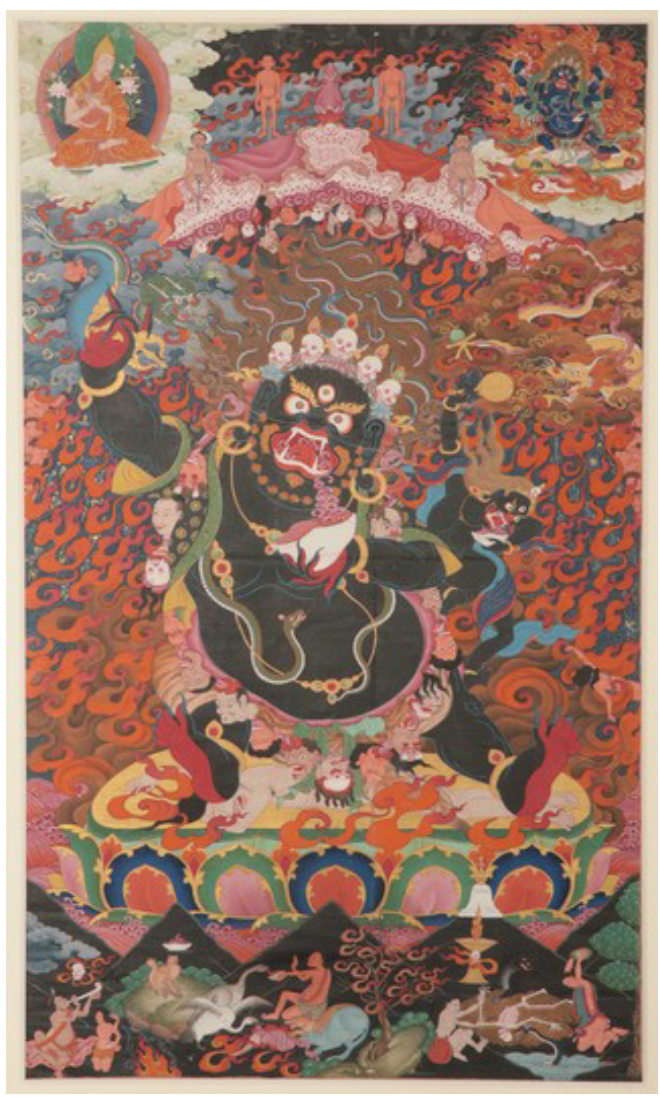

Kartaridhara is wrathful in appearance, dark in colour, with one face and two hands. He holds upraised in the right a curved knife (kartari). In the left he holds a skullcup to the heart. Kartaridhara can be found in the NartangGyatsa publication. There are several traditions of practice. The famous is that of JowoAtisha.

According to the Panjarnata system of Mahakala there are two forms of the deity that have the same appearance as Kartaridhara. The first form is 'Copper Knife' Mahakala associated with the Eight Deity practices of PanjarnataMahakala. The second is associated with the Seventeen Deity Panjarnata Mandala. (Jeff Watt 8-2017) 
- BrahmarupaMahakala (Tibetan: gonpo dram ze. English: the Mahakala who appears in the form of a Brahman). Sanskrit: Brahmarupa Tibetan: Dram ze

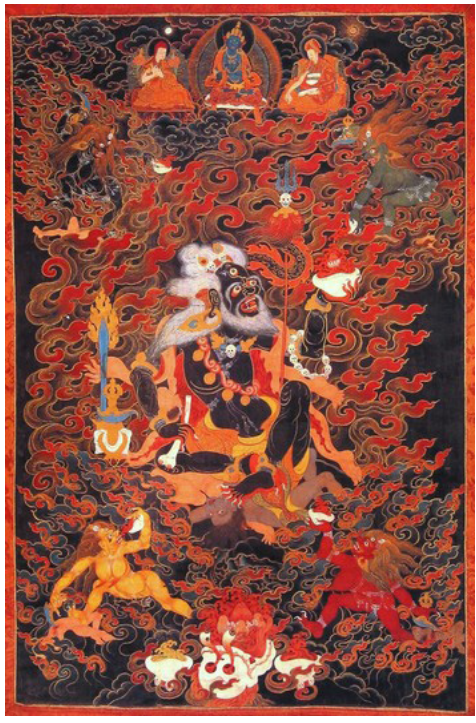

Appearing as an Indian Brahman, dark brown in colour, he has one face and two hands. With the right hand he holds a human shin-bone trumpet and in the left, upraised, a human skull filled with blood. The hair, beard and eyebrows are white. Wearing bone ornaments, intestines and a human skin he sits atop a human body.

At the edges of the pristine awareness wisdom fire are four dakinis, ghoulish in appearance, dynamic in posture, Dombini, Chandali, Rakshasi and Singhali Devi - black, red, yellow and green. They are naked with disheveled orange hair, each holding a curved knife and a skullcup.

\section{The Story}

When the great Tibetan Translator Nyen Lotsawa received the Manjuvajra Guhyasamaja (also known as the Jnanapada Lineage) empowerment from the dakini Risula, she also bestowed the initiation of the Mahakala (Chaturmukha) in the special form according to the Guhyasamaja Tantra.

At this time she gave him as a servant a dark skinned Brahman. When Nyen Lotsawa and the Brahman reached Nepal the servant changed appearance and took on the form of a monk, an appearance more conducive for travelling in Tibet. After the passing of Nyen Lotsawa the monk remained with Lama Nam Ka'upa and then later with Sachen Kunga Nyingpo.(. Jeff Watt 8-2005 )

The objective of Mahakala practice is to assist practitioners in removing any challenges that impedes their spiritual practice, as well as to encourage exertion and devotion 
and at the same time purify obscuration and defilements. With earnest prayer and diligent practices, blessings will be bestowed and obstacles will be pacified.

The Buddhist claim that Mahakala is the protector of Dharma and religious law, while the Hindus claim him to be "the great destroyer" and consider that death is not the end but it is the beginning of new-life.

\section{Reference}

Chaturvedi, B. K. (2006), Shiv Purana (First ed.), New Delhi: Diamond Pocket Books.

Emi, M. (2001). Iconography of Mahākāla. M.A. Thesis, The Ohio State University. Retrieved from http://rave. ohiolink.edu/etdc/view?acc_num=osu1141933891

Kalsang, L. (1996). The guardian deities of Tibet. Delhi: Winsome Books.

Kinsley, D. R. (1997). Tantric visions of the divine feminine: The ten mahāvidyās. USA: University of California Press.

Lorenz, E. (2007). "The Harivamsa: The dynasty of Krishna". In Edwin F. Bryant (ed.), Krishna, A source book. London: Oxford University Press.

Linrothe, R. (1999). Ruthless Compassion: wrathful deities in early Indo-Tibetan esoteric Buddhist art. London: Serindia Publications.

Muller, M. Shvetashvatara Upanishad, The Upanishads, Part II. London: Oxford University Press.

Maithily, J. (2005). Hindu custom and traditions. Pune: Abhinav Publications.

Mookerjee, A. (1988). Kali: The feminine force. New York: Destin Parashara M. Brihat

Parasara. (1994). Hora Sastra: Guide to Hindu Astrology. In: Sharma GC, (ed.). New Delhi: Sagar.

Robert, H. (1921). Shvetashvatara Upanishad, The thirteen principal Upanishads. London: Oxford University Press.

Shaktisamgama Tantra, Kali Khanda.

Stablein, W. (1976). The Mahakalatantra: A theory of ritural blessings and tantric medicine. Ph.D. Dissertation, Columbia University.

Woodroffe, J. G. (1951). Shakti and Shâkta: essays and addresses on the Shâkta Tantrashâstra. 